\title{
THE EMBODIMENT OF INTERTEXTUALITY IN MODERN LITERATURE
}

\section{Statkevych L. P.}

\section{INTRODUCTION}

Since its first introduction in 1966 by post-structuralist Julia Kristieva, the term "intertextuality" has come to catch up constantly increasing interest in modern literary discourse. However, it has been adapted and used so many times that it has accumulated a wide range of meanings which makes it necessary to start this paper by highlighting the different meanings associated with this term with special focus on its use in modern literary theory. The notion of intertextuality is compulsory for all texts. This category of intertextuality is defined as a dialogical connection between the text and the preceding text as well as further text generations. Therefore, intertextuality is a high-powered phenomenon that creates world literature. In this manner, intertextuality creates a network of different literary texts of different authors from different countries, cultures and epochs. Intertextuality is a process of multidimensional integration of the text into another by means of "rewording of the original". Intertextuality is expressed in the text through quotations, allusions, reminiscences, mythologemes and mythems, migrant themes, plagiarisma and motifs and so on. Therefore, intertextuality has a paradigmatic nature and buries a text in a continuum of the culture of a whole civilization and world literature. Semantically, intertextuality performs a text creation function with the help of quoting other texts. Prevailing as both a generic text category and the key principium of the modern postmodern culture, intertextuality, still, has not been analyzed in a scrupulous and non-contradictory way until now. By definition, the theory of this phenomenon is engaged with the analysis of the text and the variety of verbalization of all their intertextual relations. The main thesis of the theory of intertextuality is that due to its signifying nature, each text exists in interrelation with all other texts; and these intertextual connections actualize in the moment of its comprehension.

The intertextually oriented poetics of writers make it possible for a full dialogue not only between individual authors, but also more broadly, national cultures and artistic and aesthetic systems. The analysis of intertextual connections significantly influences the understanding of 
specific works, including the literary process in general. At the present stage of its development, fiction delves into self-knowledge and seeks immanent sources and forms of self-development.

It means that intertextuality creates a network of different literary texts of different authors from different countries and cultures. It means that intertextuality creates a network of different literary texts of different authors from different countries and cultures. Intertextuality has also been studied as an integration of one text into another by means of "rewording of the original". Intertextuality has also been studied as an integration of one text into another by means of "rewording of the original" Intertextuality is expressed in a text through quotations, allusions that create multiple associations hinting at the events, facts, characters of other texts, reminiscences, migrant themes, borrowings etc.

So, the phenomenon of intertextuality is compulsory for all the texts; it is realized in a text, which consists of quotations and is a result of absorbing and transforming other texts, being a point of embodiment of frequentative meanings. The better the reader is familiar with the relevant precedent texts, the more elements of semantics, linguistic and stylistic organization of the receiver's text will be comprehended in connection with similar details of these precedent texts and the more comprehensively the process of text comprehension will turn up by the reader.

\section{Theoretical aspects of the problem of intertextuality}

The term "intertextuality" was introduced into the terminological apparatus of all philological sciences in a situation of increased instability, dynamism and growing priority of cultural innovation. For theoretical and critical studies on innovation and tradition, progressive cultural achievements and ideas of continuity in the development of the spiritual life of humanity had to use new tools, a qualitative methodological approach, and more ways that this approach has already been prepared by compelling cultural studies ${ }^{1}$. Thus, favorable conditions have developed and there was an urgent need to synthesize previous scientific experience in the study of the dialectical of literature. That is why, in the context of related philological studies, the problem of intertextuality in the literary process has become the object of scientific interest of many researchers, due to its actualization by symbolists, modernists and postmodernists. Among the scientists who have been engaged in and continue to develop

${ }^{1}$ Пономаренко І. В. Художня своєрідність поезії Ліни Костенко (інтертекстуальність і феномен Агону): Дис. ... кандидата філол. наук: 10.01.01; - Захищена 18.01.2006; Затв. 13.04.2006. - К., 2005. 190 с.: іл.-Бібліогр.: с. 173-190. - С. 130. 
this theory are Bakhtin, Kristeva, Barthes, Genett, Riffater, Lotman, Arnold, Zholkovsky, Fomichyov, Moskvin, Galperin, Fateeva, Denisova, Kuzmina, Smirnov, Torop, Zubrytska and others. Despite all the different concepts and approaches to the study of this philological phenomenon, all theoreticians of intertextuality are unanimous in that "the significance of the concept of intertextuality goes far beyond the purely theoretical understanding of the modern cultural process, since it corresponded to the in-depth inquiry of world culture with its conscious or unconscious desire

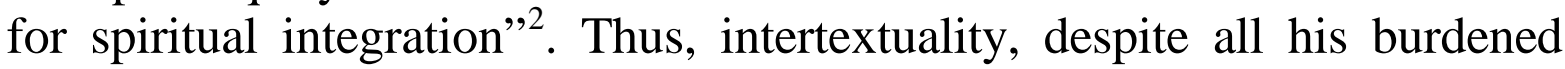
pessimistic "all words were once somebody's" has great potential not only in the literary and imaginative simulation of reality, but also in the analysis of literary works. To solve the tasks we must first clarify the meaning of the terms "intertextuality" and "intertext". In modern scientific discourse there are many definitions of the concept of "intertextuality". It is connected with such spheres of its use as: 1) the stylistic dominant of poetics as a separate artist, and aesthetically styled modus; 2 ) the method of linguistic analysis and interpretation of texts. Each text is an intertext; other texts are manifested in it at different levels in more or less recognizable forms: the texts of the previous culture and the texts of modern culture. Any text is a new canvas made from old citations. Excerpts of cultural codes, formulas, rhetorical structures, fragments of social idioms, etc. - all of them are dissolved in the text and mixed in it, since there is always language to and around the text as a necessary condition for any text existing. Intertextuality cannot be confined to the problem of sources and influences: it is the general field of anonymous formulas, whose origins can be rarely identified, unconscious or automatic quotes presented without quotes ${ }^{3}$. The understanding of this phenomenon proposed by R. Barthes and J. Kristeva is its philosophical basis.

Considering the significant number of interpretations of intertextuality in scientific discourse (as a rule, they often duplicate each other), we see the need to focus on the key interpretations. Thus, an overview of the definitions of the process of the text creation given in the "Anthology of the World Literary and Critical Thought": "Intertextuality (mizhtekstualnist) (Franc. Intertextualite) - means a method of studying text as a key system in relation to other systems, as well as the interaction of different codes, discourses or voices interlaced in the text. U. Eco considers intertextuality as a kind of "transcoding", which sets the

\footnotetext{
${ }^{2}$ Селиванова Е. А. Основы лингвистической теории текста и коммуникации. - К.: Издательство украинского фитосоциологического центра, 2002. - 336 с. - С. 221.

${ }^{3}$ Барт Р. Семиотика. Поэтика. - М.: Прогресс, 1994. - 616 с. - С. 62.
} 
framework for linking text with other similar texts. French theorist of literature M. Riffaterre distinguishes the intertext as a collection of texts that correlate with the text we are considering, and intertextuality as the process of perceiving the value of the text. The representative of the Geneva School of Phenomenological Criticism, Jean Genet, narrows the

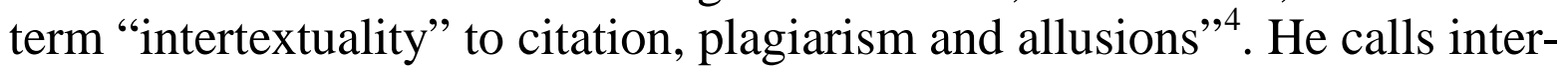
textuality the ability to partly or completely form the text's meaning by referring to other texts. In his view, this phenomenon of text-creation has such an option of implementation as "a text in the text". "A text in the text is a special rhetorical construction, in which the difference in the codification of various parts of the text becomes a detected factor in the author's construction and the reader's perception of the text" ${ }^{\text {. }}$. Moreover, such a poetic text Y. Lotman calls "semiotically rich". He suggests, to examine and to go behind not the text in general, in the broad sense of the word, but a certain text that performs two functions - an adequate transport of meanings and the generation of new meanings. It is this property of "someone else's word" that defines a multilevel approach to the study of intertextuality as a process of developing literature, as the art of the word, and at the same time as a category of analysis of a work of art.

Thus, intertextuality is, in a sense, synonymous with textuality, since these categories are inherent in every text. We will not be original, arguing that intertextuality is a goal and a means of text-creation. This is because the process of text-creation involves two components: the question of intertextuality, that is, motif, plot and character pragmatics, and the question of intrinsic textuality, that is, linguistic compositional syntagmatics. Intertextuality is distinguished by the high-potential ability of text-creation and is a metatext category of the evolution of the poetic (and not only) language. Quite close to these definitions is the understanding of intertextuality as a "simultaneous presence" in a single work of two or more texts - in the western linguistic tradition it belongs to G. Genette, and in Russian - to V. Rudnev. In turn, N. Fateeva considers intertextuality as a "mechanism of metamorphic reflection" . The researcher, in particular, believes that the further retreat of the intertext from the prototext is, the more powerful the actual moment of their interaction is actualized. "In this sense, the intertextual game, on the

\footnotetext{
4 Слово. Знак. Дискурс. Антологія світової літературно-критичної думки ХХ ст. / За ред. М. Зубрицької. - Львів: Літопис, 1996.- 633 с. - С. 608.

${ }^{5}$ Лотман Ю. М. Текст у тексті // Слово. Знак. Дискурс. Антологія світової літературно-критичної думки ХХ ст. / За ред. Марії Зубрицької. - Львів: Літопис, 1996. - С. 428-442. - С. 436.

${ }^{6}$ Фатеева Н. А. Контрапункт интертекстуальности, или интертекст в мире текстов. - М.: Агар, 2000. $-280 \mathrm{c}$.
} 
one hand, is also one way of reducing the time perspective: attention is focused not on it, but on the degree of its distortion"7. As already noted, all the above interpretations of the phenomenon of intertextuality to some extent overlap each other. Therefore, it is easy to track the commonality of all such an indication of intertextuality, as a dialogical modality (external or internal motivation for dialogue) which is realized: 1) through textual interactions within the separate text; 2) the way in which the intertext reads the history of literature and culture in general. As for the term "intertext", then there is no complete terminological coherence; to a certain extent, this can be explained by the fact that scientists belong to different schools and the priority of different concepts. Thus, for example, the intertext in the scientific discourse is called:

- any text that is always "a new canvas made of old quotations" (R. Barthes);

- several works or their fragments, forming a single text (intertextual) space (O. Zholkovsky, I. Smirnov, N. Fateyeva);

- intertext that is "1) a verse composed of different poems of one or several poets, 2) a work rich in quotations, reminiscences, allusions, etc." 8 . Such a text was characteristic of the literature of post-modernism (J. Kristeva, V. Rudnev, G. Genette);

- subtext as a component of the semantic structure of the work (P. Tammi, G. Frege, M. Riffater, S. Zolyan);

- objective information reality, which is the product of the creative activity of a person who has the ability to infinitely self-generating in time (Y. Lotman, J. Derrida, N. Kuzmina).

For scientific use the term "intertextuality" was proposed by J. Kristeva in the article "Bakhtin, Word, Dialogue and Novel" (1967) ${ }^{9}$. The object of the proposed study by J. Kristeva was the work of M. Bakhtin "The Problem of Content, Material, and Form in Verbal Art" (1924). In this work, the scientist, exploring literary dialectical process concludes that "any author also deals with the literary tradition and contemporary literature with whom he is in constant "dialogue”. Thus, intertextuality is an identified dialogue of texts as signs of the particular culture. The main idea of J. Kristeva theory is that the text constantly absorbs and transforms, creates and re-thinks: as a result of this text

\footnotetext{
${ }^{7}$ Фатеева Н. А. Контрапункт интертекстуальности, или интертекст в мире текстов. - М.: Агар, 2000. - C. 14.

8 Лексикон загального та порівняльного літературознавства. - Чернівці: Золоті литаври, 2001. 636 с. -612.

9 Кристева Ю. Бахтин, слово, диалог и роман // Французская семиотика: от структурализма к постструктурализму / Под. ред. Косикова Г. К. - М.: Прогресс, 2000. - С. 427-457.
} 
creation process, "poetic language can be understood ambiguously"10. J. Kristeva first identified intertextuality as one of the global categories that characterizes the consciousness of the culture of the second half of the XIX - XX centuries that is represented by the aesthetic systems of Symbolism, Modernism and Postmodernism. However, it should be noted that the phenomenon of intertextuality is not an innovation of the literature of Symbolism, Modernism or Postmodernism. It is well known since the time of Homer, because those stylistic means used by the great ancient poet certifying organic connection Homeric epic with folk origins. The folk heroic epic of the early Middle Ages is an individual creativity within the framework of a collective tradition. In general, the tendency for self-knowledge and the search for sources for text-generation within itself was outlined in the literature long before Symbolism, Modernism and Postmodernism. The image and text "migration" is characteristic for the literary works of each writer and each particular literary and aesthetic system as a whole. Particularly active writers rethink in the contexts of their works myths, legends, ancient and sacred texts, works of Dante and Shakespeare, who, in essence, are precedent donors of text-formation to this days. Undoubtedly, only a subjective factor plays a dominant role in the selection of material for literary rethinking. And it depends not only on the author's personal aesthetic tastes, his thesaurus or the literary mode of his time, but also on the range of philosophical, aesthetic and moral themes that are supposed to be considered in the work. This confirms the hypothesis, the essence of which is already determined in the teachings of O. Veselovsky, that the history of literature - is the history of texts, in other words, the history of intertexts. The writer creates his text from the forms already loaded with content filled with them; these forms are revealed only in the favorable for the disclosure of semantic cultural contexts of forthcoming eras.

Thus, the development of literature is in the early stages of its origin and formation indicates the widespread use of established form-content elements. Their use in the process of text creation can be done both consciously and unconsciously. T. S. Eliot reflected in his culturological works on the conscious and unconscious borrowing of "a strange word": he said that every author owes much from different poets. There are poets who are remembered as an example of certain poetic merits, such as Villon - honesty and Sappho - just like fixing certain emotions and using only minimal required set of words. There are also great masters -

10 Кристева Ю. Бахтин, слово, диалог и роман // Французская семиотика: от структурализма к постструктурализму / Под. ред. Косикова Г. К. - М.: Прогресс, 2000. - С.. 427-457. 
samples to grow. The problem of influence and literary borrowing is traditionally considered in the psychological aspect, because literary borrowing is a deliberate and motivated act of the writer, while the impact is largely a natural process: the writer may not be aware of its results or do it post factum. Both influence and literary borrowings in the author's own text generate both predictable and unpredictable subtexts. The practice of intertextuality further expanding its field of activity is also because it is tangent to the overall situation of quotation in post-modern thinking, which is characterized not only by the literature and art, but also by a universal culture. In the concept of post-structuralism, the phenomenon of intertextuality is considered in the light of the theory of Derrida that "the world is a text". In accordance with this concept, all human culture is analyzed as a single text field. Its basis is the only prototext: the cultural context and all literary tradition. Having a single universal prototext, the literary work has been intertextual since its “origin” in the author's imagination, since it is both an integral part and a means of creating a single cultural and semiotic environment. In other words, the phenomenon of intertextuality states not only the fact of borrowing certain elements in structured before, already written texts, but also the availability of a universal text space - the information and energy field, which in cultural essays T. S. Eliot calls tradition, Y. Lotman semiosphere, V. Vernadsky - noosphere. Y. Lotman used the term "semiosphere" to refer to the entire oral and written culture of human civilization. He believed that "all semiotic space can be regarded as a single mechanism $<\ldots>$. Semiosphere - this is the semiotic space outside, beyond which the existence of the semiosis is impossible" ${ }^{11}$. Recently, in the scientific discourse, the notion of "linguistic and cultural consciousness", which is formed in the sphere of the linguistic and cultural space, was undoubtedly relevant. In fact, for each individual language to some extent affect intertext, while individual language itself becomes a subject who actively use them, organizes and regulates according to its "image of the world". These "communication unit" cultural cliches are parts of the national cultural memory of a certain culture. However, they are invariant form images of the world, without which no communication system can exist. G. Denisova and N. Kuzmina convincingly prove that in the "linguistic space of each linguistic person a presumption of intertextuality is laid down, which is an integral part of the

11 Кузьмина Н. А. Интертекст и его роль в процесах эволюции поэтического язика. - М.: Едиториал УРСС, 2004. - 272 с. - С. 14. 
negotiated readiness of each native speaker, creating its text potential"12. In the study of intertextuality - the dominant phenomenon of the evolution of literature - quite resonant is also the thesis that the sphere of cultural memory as the basis of the presumption of intertextuality, consisting of "strong" precedent texts and "weak" ones contained on the periphery of cultural space. "Strong texts and authors, around which unfolding the true process of literary evolution, are connected by intertextuality in an absolutely special way. Quotation is paradoxical way of establishing originality. Each national culture, as well as every era, qualitatively changes the list of precedent texts, leaving unchanged its core, the myths, the Bible, Dante, Shakespeare and others. For example, for the Russian literature such nucleus is O. Pushkin, for the Ukrainian T. Shevchenko, for the Chinese - Lu Xun, and so on. From this variety, every writer distinguishes well-known, semantically completed images, the use of which not only enriches the polyphony of the intertext, but also makes the text multilevel. At the same time, the number of levels is adequate to the number of prototypes, where this image operates. To identify such images the term "poetic paradigm" was introduced (M. V. Pavlovych). The images that make up the poetic paradigm always implement a certain general idea, model, or framework. The fundamental difference between the forms of intertextuality and the poetic paradigm of M. V. Pavlovych is that the presence of a community of ideas or images allows the recipient to understand the text without focusing on a particular context. So intertextuality requires from the recipient to have the same background knowledge as the author. So, it is the only text space of universal traditions that enables free and productive text selfgeneration. Thus, intertextuality is not only a necessary condition for the existence of every culture (semiosphere), but also acts as its high-potential creative element. In essence, it is a necessary component of the evolution of the poetic language as, indeed, any kind of art.

It is the desire to say a new word forcing writers to seek new content and forms of expression of their own worldview, making maximum use of opportunities potentially laid in the structures with vertical context, where intertextual links are brightly designed. In view of this, the dominant factor of poetics of the XIX and especially of the XX century theorists of intertextuality determine literature centrism. It is clear that in the cultural tradition literary works cannot exist in isolation, they intertwine and absorb each other, while not only creating a new aesthetic integrity, but also getting enriched by the powerful energy of previous

\footnotetext{
${ }^{12}$ Денисова Г. В. В мире интертекста: язык, память, перевод. - М.: Азбуковник, 2003. - 297 с.
} 
eras. T. S. Eliot was deeply convinced that the poet actualizes the prospect of fruitful development of literature, only creatively rethinking the achievements of his predecessors. That is why, in his opinion, the poet must have a historical sensation. "Historical sensation" in his understanding is nothing more than a dynamic integrity of the preservation and development of cultural tradition. "Although in this case, T. S. Eliot operates the notion of "historical" - rightly observes O. Kozlov, - here we are talking about the transistorical aspect of poetry or, using the terminology of linguists, about its "synchronous cut" ${ }^{13}$. Of course, T. S. Eliot did not use the term "intertextuality" in any of his culturological works, (for objective reasons: this definition was introduced into scientific discourse two years after the death of the poet), but it is quite obvious that he meant this particular process, which V.S. Bibler called "a dialogue of cultures, a dialogue of cultural contexts", defining the aforementioned philological phenomenon ${ }^{14}$. Of course, in literature, especially in poetry, tradition plays a special role: "Every truly creative voice can always be the only second voice in the word. <..>. The writer - a man who has the gift of speaking indirectly" ${ }^{\prime 15}$. As literary integrity is always created during polylogue between the authors, the reader and the historical space that separates them, then the process of reception should also be taken in a certain sense part of this polylogue. Thus, the defining feature of any interaction is polyphony. J. Kristeva introduced the term "interaction" to scientific discourse: "We call intertextuality this textual interaction which occurs within a particular text" ${ }^{\text {16 }}$. Verbal-mental inclusion in the text is not only an integral part of its form-content unity, but also acts as a "shifted" element, which presents new subjects of speech, since "a strange word" in the course of the history of its literary use has several subtexts. P. Tammy developed the theory of the subtext. He was guided by the notion of the "polygenetic" of the text, which is implemented in the case when "in a separate segment of the text is actualized not only one subtext (as a literary source), but the whole plurality of sources”. Typically, there are two types of polygenetic coherency. The first type of inter-text interaction is expressed by the formula $T^{3} \leftarrow T^{1}+T^{2}$. In this case, a

\footnotetext{
${ }^{13}$ Козлов А. С. Литературоведение Англии и США ХХ века. - М.: Московский лицей, 2004. 256 c. - C. 31.

${ }^{14}$ Библер В. С. От наукоучения - к логике культуры: Два философских введения в двадцать первый век. - М.: Политиздат, 1991. - 413 с. - С. 286.

15 Бахтін М. Проблема тексту в лінгвістиці, філології та інших гуманітарних науках // Слово. Знак. Дискурс. Антологія світової літературно-критичної думки ХХ ст. / За ред. Марії Зубрицької. Львів: Літопис, 1996. - С. 321-322.

${ }^{16}$ Смирнов И. П. Порождение интертекста (элементы интертекстуального анализа с примерами из творчества Б. Пастернака). - СПб.: Изд-во С.-Петерб. ун-та, 1995. - 191 с. - С. 205.
} 
certain fragment of the new text correlates with two (or more) contexts that are not interconnected. The second type is called "subtext in the subtext": used prototexts meet within each other, what reconstructs their historical and literary connection. Schematically this type can be represented by the formula $\mathrm{T}^{3} \leftarrow \mathrm{T}^{2} \leftarrow \mathrm{T}^{1}$. It is clear that $\mathrm{T}^{3}$ is an intertext; $\mathrm{T}^{1}$ and $\mathrm{T}^{2}$ are the earlier literary rethinking of a particular plot, motif, or image. Despite the number of fundamental works on intertextuality, the problem of intertextual relations is set by the literature itself. And it cannot be fully considered and developed either in the theoretical and methodological aspects, or in the terminology. More than forty years of development of intertextual analysis have shown both its positive features and explicit constraints. Ample material has been accumulated, but it is not clear how identifiable subtexts function in the structure of poetry. Scientists have repeatedly raised questions about the priority methods of intertextual analysis.

In particular, there were attempts to oppose the intertextual analysis to structural: it was said that structural analysis belongs to Structuralism, and intertextual - to Post-structuralism, which deconstructs it by splitting the text into the textual. Regarding the term "text", we note that P. Torop proposed it to scientific discourse. Explaining its importance, scholar wrote: "Some of the text that links specific text with another text, requires first of all recognition $<\ldots>$. To interpret such a part, it is necessary, firstly, to identify its function in the text, and secondly, to fix the actual connection with the source text $<\ldots>$ »17. This, according to M. Riffaterre position, suggests that text and intertext are not related to each other as either "a donor or a recipient", and their relationship is not limited to "borrowings" and "influences". In this case, thanks to the interpreter, there is a mutual transformation of the meanings of texts that have entered into interaction. "Strange Word" in the text sends the reader to its own prototext, so the violation of the linearity of the recipient text requires a new way of reading and decoding, taking into account the dynamics of subtexts. Currently, there is no doubt that each literary work is an intertextual, and therefore, characterized by a plurality of subtexts. Given this, it is absolutely clear that intertextuality is a category of hermeneutics. Taking into account the reflexivity of the literary process, it should be noted that the interpretation of any communicative action should be perceived as a "translation" of the code of the writer into the reader's code, because of the uniqueness of linguacultural consciousnesses cannot completely coincide (Y. Karaulov).

17 Тороп П. Х. Проблема интекста // Труды по знаковым системам. Вып. ХIV. Текст в тексте. Тарту: ТГУ, 1981. - С. 33-44. - С. 39. 
Since intertextual analysis often provokes the appearance of different (sometimes polar) subtext decoding options, we consider it necessary to focus on the problem of textual interpretation. Moreover, in the scientific discussion intertextuality is divided into the author's and the reader's. For example, N. Fateyeva believes that "from the standpoint of the author, intertextuality is a way of genesis of his own text and postulating his own poetic "I", through the complex system of oppositional relationships, identities and masking with the texts of other authors (that is, other poetical "I")"18. It is this moment of meta-thinking and meta-description that emphasizes the dialogue of literary texts. From the standpoint of the reader, intertextuality is the setting of 1 ) a deeper understanding of the text or 2) decoding of the text (text anomalies) by establishing links with other texts $^{19}$. It is with the reader intertextuality that the problem of distinguishing the stages of perception of the text: the actual perception, understanding and interpretation. Long before the emergence of the theory of intertextuality O. Potebnya repeatedly emphasized that to percept does not yet mean to understand ${ }^{20}$. In contrast to the actual perception and understanding is the process of assimilating the inner depth of the system of subtexts or meanings.

It is advisable to state the impossibility of a clear distinction between reading, understanding and interpretation. Analysis of the conflict of interpretations, various subtexts of the work is the field of studying hermeneutics and psycholinguistics. I. Arnold, while engaged in the interpretation of the text, calls hermeneutics "a science not about formal but about the spiritual interpretation of the text" ${ }^{21}$. In this vein, the opinion of T. S. Eliot is interesting, he expressed it long before the actualization of the problem of adequate interpretation of subtexts in the intertexts among scholars: "poetry is a form of "communication", since the message itself is a poetic essay, as well as <...> the experience and thoughts available in to him. A poetic work exists somewhere between the author and the reader; it is enriched by a reality that is not identical only to the reality of what the author tries to "express" or the reality of the author's experience in writing this work, either the experience of the reader, or the reader's experience of the author. This is connected with the

\footnotetext{
18 Фатеева Н. А. Контрапункт интертекстуальности, или интертекст в мире текстов. - М.: Агар, 2000. - 280 с. - C. 20.

${ }^{19}$ Ibid. P. 16.

${ }^{20}$ Потебня О. Думка і мова // Антологія світової літературно-критичної думки ХХ ст. / За редакцією Марії Зубрицької. - Львів: Літопис, 1996. - С. 25-39.

${ }^{21}$ Арнольд И. В. Читательское восприятие интертекстуальности и герменевтика // Интертекстуальные связи в художественном тексте. - С.-Пб.: Сотворение, 1993. - С. 4-12.
} 
question that a literary work "means" a more complex phenomenon than it first appears" 22 .

I believe that anybody could only convey an opinion to someone who is ready to accept it, because it only stimulates mental activity of a person who forms an opinion from his own picture of the world. So, understanding the text on all levels impulses the reader to create his own idea, insight and vision. And one who understands never remains in his own world, on the contrary, he converges in a new world, third world of communication, they (author and reader) communicate with each other and knot an active dialogical relationship. So, dialogue relation is complicated by the fact that any interaction is always realized in two manifestations: implicit and explicit. Explicit interaction, that is, verbal, obvious presence in the product of someone else's word always generates implicit meanings. The function of implicit meaning in the literary work is of interest to both literary critics and linguists, psychologists and psycholinguists, since it directly relates to the adequate (implicit sense) decoding. Explicit interaction, that is, verbal, obvious presence in the literary work of someone else's word always generates implicit meanings. For the literary study, the most important is the definition of the implicit as a hidden, non-verbal information of the inference that mediates the transition from one statement to another in the absence of their explicit (obvious, that is, verbal) communication. In fact, the process of decoding implicit meanings is a subjectivized process, since it is based on the identity (or not identity) of the author's and reader's thesaurus. According to the theory of communication, the implicit is primarily a collection of non-verbal information arrays, which in the work integrate with the verbal code of the text. In the linguistics of the text most commonly used is the understanding of implication as a semantic block of content that arises based on an explicit textual structure and is lined up by it because of decoding by the reader. In this case, the implication is often identified with the subtext, which is formed because of tricks of the recipient of those ideas that are laid down in it verbally. Consequently, implicit meaning is hidden information of the text, which does not necessarily occur when decoding logical connections in the intertextual way. For the most part, it is related to the semantics of the literary work, for example, polysemy, or it is determined by its context, the reader's thesaurus, and so on. It is necessary to say a few words about the delimitation of the concepts of "implicit meaning" and "subtext". The notion of "subtext" is

22 Элиот Т. С. Традиция и творческая ндивидуальность / Пер. А. Зверева. // Писатели США о литературе. В 2 т. - М.: Прогресс, 1982. - Т. 2 - С. 12-19. - С. 56. 
used both in the narrow sense of the "contextual meaning of the word", and in the broad sense - "the untrue discourse" ${ }^{23}$. For our research, the second definition is important because it treats the subtext as a parallel reality, which makes it possible to refer (i.e. the possibility of associations and references to external information) to the literary text and, to a certain extent, is its essence. Thus, the subtext is a parallel content, a specific conceptual space created by the implicit meaning of text concepts. As for the implicit meaning, it is a broader concept that applies to all hidden (not expressed explicitly) information of the text. In this context, the subtext can be understood as concealed text information that is decoded based on the context, the contextual meanings of the individual words and, of course, the reader's thesaurus. Thus, the representation of someone else's voice into the space of another picture of the world always performs a semantic function. Any explicit manifestation of "someone else's word" in the text saturated with other informational and emotional connotations. Transformed text borrowing becomes a carrier of new message inherents in its prototext. Such transformation in a new context may be completely unpredictable, which ultimately leads to a change in the connotations within the intertext. The analysis of inclusions of texts in the text of literary work gives grounds to consider them as one of the most important methods in the poetry. Re-coding someone else's system of aesthetic means for his own literary purpose, the writer counts on reading his work in the metaliterary key. As the practice of intertextual analysis of the literary work shows, intertextuality is often associated with intratextuality (the term introduced by L. Orr) or auto-intertextuality (the term of $\mathrm{N}$. Fateeva), which establishes intertextual connections in the structure of the author's idiostyle. Both categories are characterized by pronounced reproductive capacity. However, the task of intratextuality is to actualize what has been said in the author's metatext, while the task of intertextuality is to comprehend, and therefore to update borrowed from another. Autotextuality always acts as an intertextuality in the square, since the author in his own metatext uses his word as a prototext, generating a system of leitmotifs. Due to the systematization of manifestations of autointertextuality, one can trace the hierarchy of dominant motifs in the work of the writer. Recent studies of literary works through intertextual analysis are based on tracking their typological motifs in the system of fiction. It is the semantic relation of the motif to the plot, and not to the plot, in fact, is the "vector" that sets

${ }^{23}$ Руднев В. П. Словарь культуры ХХ века: Ключевые понятия и тексты. - М.: АГРАФ, 1999. 381 c. - C. 256. 
the direction from the thematic concept of the motif to its intertextual interpretation. French scholar J. Dugast notes that due to the extensive system of the text and subtext motifs, "the act of reading is no longer reduced to the fact that the reader follows a predetermined direction of the narrative - reading becomes an act of decoding $<$... $>$,24.

It is necessary to point out a rather important motif function decoding the author's intention and updating the reader's co-creation. Despite the fact that scientists have repeatedly raised the questions of intertext for more than thirty years, however, we are currently only recording four attempts to classify different types of the texts interaction. In the article "The problem of the text" (1981) P. Torop has offered the first classification. The scholar considers any act of the ratio of text elements as metacommunication, the result of which are metatexts. By studying intertextual connections within a separate text, P. Torop introduces the concept of the text as a "semantically saturated part of the text, the meaning and functions of which are defined by at least a double description (in this sense, it is a twotext)" ${ }^{\text {,25 }}$. The scientist distinguishes between the following types of information: precise translation quotation, cinton, application; formal (macro-stylistic) translation pastiche; quotation translation - periphrasis; speech (micro-stylistic) translation - reminiscence, stylization; descriptive translation paraphrase; thematic translation - antonomass, adaptation; free translation - allusion; expressive translation - burlesque, travesty. A year after the work of P. Torop, G. Genette proposed his own five-member classification, presented in the well-known book "Palimpsesty: Second Degree Literature" (Genette G. Palimpsestes: La literature an second degree - P., 1982). He highlighted, above all, his own intertextuality, which manifests itself in the simultaneous presence of elements of other texts in the same text (citations, allusions, plagiarism). The scientist interprets paratextuality as the relation of the text to its part (header, epigraph, etc.). According to the researcher, meta-textuality involves commenting the text of the text on its prototext (variation, remake). J. Gennett considered the basis of hypertextuality to be a parody of the transcript of the text (paste). Architecturalism is a genre of communication between the texts. All listed varieties of intertextuality can be simultaneously actualized within the same text. N. Fateyeva has offered the following classification:

\footnotetext{
${ }^{24}$ Dugast J. Themes et motifs dans le roman contemporain. "La Pensee”, 1971. № 158. - P. 82-103.

${ }^{25}$ Тороп П. Х. Проблема интекста // Труды по знаковым системам. Вып. ХIV. Текст в тексте. Тарту: ТГУ, 1981. - С. 33-44.
} 
I. Actually intertextuality, which forms the construction of "text in the text".

1.1. Quotes;

1.1.1. Citations with attribution;

1.1.2. Quotes without attribution;

1.2. Allusions;

1.2.1. Allusions with attribution;

1.2.2. Allusions without attribution;

1.3. Pastiche, that is, a complex of allusions and citations;

II. Paratextuality or the relation of the text to the title, epigraph, epilogue.

2.1. Quotes-names;

2.2. Epigraphs;

III. Metatext as a translation and commenting on the prototext.

3.1. Intertext- retelling;

3.2. Variations on the theme of prototext;

IV. Hypertextuality as mocking or parodying with one text of another.

V. Arhitextuality as genre link text ${ }^{26}$.

$\mathrm{N}$. Fateeva in this classification has integrated the results of previous studies.

Intertextuality in spite of all these features (an important condition for the existence of culture, the dominant factor in the evolution of literary language, the purpose and means of textual development, etc.) are a key to the preservation and development of literary tradition. O. Volodina's work "The phenomenon of intertextuality in the aspect of typology" is devoted to the delineation of intertextuality and literary tradition. In modern literature the tendency prevails to understanding the phenomenon of intertextuality as universal, inherent to all levels of the text (genre, rhythmic organization, etc.). Different approaches to the understanding and interpretation of this philological phenomenon are proposed, which, at first glance, make the definition terminologically "blurred" and, on the other hand, reflect the dominant signs of the functioning of intertextuality in certain periods of the cultural-historical process. O. Volodina does not deny the universality of the phenomenon of intertextuality, but adds to its categories, which specify the type of intertextual links: archetypal and contextual. It can be directed to the search for a specific archetype, to establish the correspondence in the rhythmic and genre organization of the work, to compare the types of artistic thinking in general: "In any

${ }^{26}$ Фатеева Н. А. Контрапункт интертекстуальности, или интертекст в мире текстов. - М.: Агар, 2000. -280 c. - C. $122-159$. 
case, reconstruction of the previous literary systems, an appeal to the historical memory of literature" 27 . Thus, intertextuality arises and operates within the literary tradition. The difference between the second type of intertextual communication is that it implies interaction between ontologically different texts. These types of intertextuality often interact in practice. O. Volodina suggested a classification of intertext links based on the establishment of the source of their borrowings I consider relevant for this analysis.

Since the consideration of all the theories that somehow or other contributed to the actualization of the intertextuality phenomenon in the field of philological studies is not the core issue of this article, I restrict myself to the mentioned, which is not only its genetic basis, but also to some extent the theoretical basis of my research. Moreover, all scholars unanimously and convincingly substantiate the idea that in modern art, as in the antique, intertextuality is a text-creating act; the erosion of the boundaries between the mystery creation and reflection takes place, and the artist acts as if in another reality: in the text of culture, in semiotic space. Thus, intertextuality should be considered as the developing phenomenon, on the one hand, in accordance with the literary tradition, the specifics of genres, and on the other, based on the connection of the objective historical or everyday situation and the content of the literary work. Considering a large number of approaches and concepts for studying intertextuality, in this article study, I will use the understanding of this process of text creation proposed by R. Barthes and J. Kristeva.

\section{Forms of intertextuality as realisation of world literature}

Despite the fact that in modern literary criticism and linguistics the theory of intertextuality has been given a prominent place, unfortunately, to date, its terminology is not fully developed. In this regard, it is worth mentioning the words of F. de Saussure, who believed that in the field of linguistic terminology, especially when it comes to the latest trends, we are "often satisfied with operations on units not fully defined" 28 . F. de. Saussure words quite clearly reproduce the situation that emerged from the conceptual-terminological apparatus of the phenomenon of intertextuality. Another, in my opinion, significant drawback is unjustified term creation. So, for example, to define graphically and attributively

27 Володина 0. В. Явление интертекстуальности в аспекте типологии // Тр. Междунар. конф. «Взаимодействие литератур в мировом литературном процессе (Проблемы теоретической и исторической поэтики)»: В 2 ч. - Гродно: ГрГУ, 1998. - Ч. 1. - С. 29-38.

${ }^{28}$ cit. by: Москвин В. П. Стилистика русского языка. Теоретический курс. - Ростов н/Д.: Феникс, 2006. -630 c. - C. 202. 
unmarked quotations, V. Moskvin introduces the term comemorat (Latin commemoratio - reminder $)^{29}$. However, for a long time the term reminiscence (Latin reminiscentia - mention) is used for identifying a similar kind of "someone else's word" in the text. So, let us focus on key concepts through which this category is implemented in the text of poetry. One of the standard forms of intertextuality, of course, is quotation. Traditionally, in the narrow sense, a quotation is a literal reproduction of a fragment of any text, with the obligatory reference to the source of borrowing. This interpretation implies the binding of three components: first, the identifier - "reproduction of a fragment of any text"; and secondly, the concretizer is verbatim; thirdly, attribution - a "mandatory reference to a source". For the traditional understanding of the quotation, there is not enough clarification - "with graphic markings". The status of quotation can receive any information that the recipient perceives as a marker of the whole. Y. Lotman, in the 1970s, demonstrated that "in the literary work all formal units of the text are semantic. Quotation feature borrowed items may determine his ability to be representing cultural meanings of different degree of generalization / specificity in intertext" ${ }^{30}$. In the practice of analyzing a literary work, primarily intertextuality, we are dealing with quotes that can only be partially interpreted in a similar way. Quotes, like a form of representing “someone else's words”, are divided into attributed and non-attributed. Attributed citation is a graphically marked reproduction of a fragment of any text with a mandatory reference to its prototext. Non-attributed quotes are entered in the literary work without graphic marking and a link to its prototext. The author, in accordance with the context of the literary work, actualizing its polyphony, if the recipient recognizes them, mostly modifies graphically unmarked quotations. If there is no moment of recognition, then "someone else's words" in the actual author's text are fully assimilated without generating implicit meanings. I. Fomenko rightly notes, "the importance is not the accuracy of the citation, but the recognition of the quotation. It is important for the reader to hear "someone else's words", and then not only the quote itself can be perceived in the generalized symbolic meaning, but the author's text will be enriched by the source text. The quotation becomes like a representative of someone else's text, the mechanism of launching associations"31.

\footnotetext{
29 Там само. С. 204.

30 cit. for: Лексикон загального та порівняльного літературознавства. - Чернівці: Золоті литаври, 2001. -636 c. - C. 163.

${ }^{31}$ Фоменко И. В. Цитата // Введение в литературоведение: Литературное произведение: основные понятия и термины. - М.: «Высшая школа», 1999. - С. 496-506. - С. 499.
} 
Reminiscence, as a form of intertextuality, is defined in the scientific literature as "tangible in the literary work the echoes of another literary work, manifested in the similarity of composition, stylistics, phraseology, and the like. This is an author's reminder to the reader about earlier literary facts and their text components. By its function, the literary essence of reminiscence is similar to stylization and allusion, however, unlike them, it is unaware of the author and arises because of the strong influence on him of the writings of other writers. If the reminiscence is the result of the author's intention (we mean conscious use of it), then in this case the recipient calculates it on a common poetic paradigm and associative perception. Thus, reminiscence is a conscious or unconscious reproduction by a poet of a familiar phrasal or figurative construction from another literary work. Of course, identifying a reminiscence in the text, focusing on its unconscious use, is difficult. V. Haliseyev understands, under the reminiscence, "images of literature in literature". Reminiscence has a wide range of functions. It can act as a mirror of the cultural background of the environment, reproducing the literary atmosphere of time; often involved in literary controversy and has a connection with the parody created earlier.

The role of reminiscences in a literary work is diverse. The author may resort to this method in order to: 1) prove his worship to an authoritative predecessor; 2) demonstrate their own discipleship; 3) rethink the tradition at a new stage of cultural and historical development; 4) enter into controversy (as a rule, with the classics); 5) create a parody.

As for the allusion, it is interpreted as "the use in the language or in the work of a well-known expression as a hint of a well-known fact, historical or everyday"32.

A researcher L. Mashkov refers allusion to "no more than a manifestation of the literary tradition. At the same time, there are no fundamental differences between imitation, conscious reproduction of the form and content of earlier works and those cases in which the writer does not realize the fact of outside influence on his creation".

L. Mashkov classifies the main features of the allusive process:

1) Allusion is a reference to a specific literary work. In this case, the writer's alive communication is conscious - it distinguishes the allusion from the traditional image, the motif or the "wandering plot":

2) about the allusion in the text "signals" an elusive word or phrase;

32 Літературознавчий сдовник-довідник / Р. Т. Гром'як, Ю. І. Ковалів та ін.- К.: ВЦ «Академія», 1997. -752 c. - C. 20. 
3) an allusive word or phrase allows linking with the relevant literary source. For a proper understanding of allusion, it is necessary to discover a concrete, fact-finding fact. In most cases, the right choice of an illuminated fact depends on a thorough and profound study of the product containing the allusion;

4) the understanding of allusion cannot be reduced only to the detection of the illusive fact, since the content of the work is enriched not only at its expense, but also through the establishment of a number of additional connections between the two works: analogies, parallels, or vice versa, opposites, antitheses;

5) the allusive process is two-way: interaction, mutual influence of the work and the corresponding source;

6) the necessary condition for an effective allusive process is the universality of the poetic paradigm or "philological minimum" $(\mathrm{L} . \text { Mashkov) })^{33}$. Recently, the research interest in allusions and reminiscences has grown due to the attention to the implicit ways of transmitting information in the text. Researchers consider allusions and reminiscences as additional, implicit meaning.

According to the source of borrowing, allusions are accepted to be divided into biblical, mythological, historical, every day and literary.

To define mythological allusions, we will use the generally accepted terms - mythologeme and mythem. The mythologeme in scientific discourse is "a clear presence in the literary work of a mythological wellknown plot, plot scheme or motif. The mythologeme is the presence of a myth in a product that structures it. <...> The most striking and brightest expressions of the mythologeme can be considered as traditional stories of the mythological genesis" is called the presence of a myth in a product that structures it. The most vivid and brightest expressions of the mythologeme can be considered the traditional scenes of the mythological genesis"34. It should be noted that, despite the length of use of these terms by literary scholars, only the authors of the "Lexicon of General and Comparative Literary Studies" (2001) made a strict terminological distinction. In this work the mytheme is considered to be "in the literature using names, realities and facts mythological genesis. The purpose of such use - to cause certain associations - allusions" ${ }^{\text {"3 }}$. The mytheme is an important part of the poetic paradigm. In the text, mythemes can act as

\footnotetext{
33 Машкова Л. А. Алюзия в романе Гофмана «Эликсиры диявола» // В мире Э. Т. А. Гофмана. Калининград: Гофман-центр, 1994. - С. 120-131. - С. 25-33.

34 Лексикон загального та порівняльного літературознавства. - Чернівці: Золоті литаври, 2001. 636 c. - C. 338.

${ }^{35}$ Ibid. P. 335.
} 
nominal allusions and reminiscences, if they have sufficient associative potential. From the quote, the text allusion is distinguished by the fact that the elements of the prototext in the recipient text are sparsed that is, they do not form a holistic statement, or are presented in an implicit form. In this case, the elements of the prototext, to which the allusion is an integument, are specified in such a way that they become nodes of the semantic-compositional structure of the intertexture. To define such forms of communication, we will use the term recently got into scientific circulation - cogenesis (English cohesion). I. Galperin interprets this phenomenon as a "special kind of communication that provides the continuum, that is, the logical sequence" 36 .

The paraphrase means "the transfer of any text in their own words, its adaptation" ${ }^{37}$. Another way to implement the category of intertextuality is to "impregnate another style" - "these are words in the lexical meaning of which there are connotations indicating their belonging to one or another style".

According to J. Fomichyova, "when shifting registers and styles, there is an opposition between the codes of two texts, which is based on intertextuality. Thus, "interspersing another style" is a piece of text not only with another subject, but also with another stylistic dominant.

When shifting styles, Z. Fomicheva emphasizes: “<...> stylistic and functional change of translated factual material $<\ldots>$ Incorporation of another style, united by a common property - a change of the subject of speech, is a kind of intertextuality, more or less marked traces of other texts". It should be noted that any distant intertextual sign in the intertexture could be perceived as an inclination of another style. The initiation of such a stylistic contrast in the text, undoubtedly, is a conscious step of the author's strategy. In any case, for the identification and adequate interpretation of the forms of intertextuality, as well as the definition of their functions in the author's own text, one must possess a certain space of literary memory that forms a poetic paradigm. That is, a holistic paradigm of texts that create a cultural context for a particular work, introducing it is in a meta text frame.

36 Гальперин И. Р. Текст как объект лингвистического иследования. - М.: Наука, 1981. 140 c. - C. 74.

37 Фомичева Ж. Е. Иностилевые скопления как вид интертекстуальности // Интертекстуальные связи в художественном тексте. - С.-Пб.: Сотворение, 1993. - С. 90-92. 


\section{CONCLUSIONS}

The problem of intertextuality is one of the topical issues in the literary critics, linguists and psycholinguists researches. There are many interpretations of such concepts as "intertextuality" and "intertext". In the course of our research, preference will be given to the understanding of intertextuality proposed by R. Barthes and refined by Y. Kristeva. World literature involves into self-knowledge and seeks immanent sources and forms of development at the present stage of its development.

It was found that interaction can be realized in two forms: singlestage and two-stage. The latter is polygenic in nature. The following types of polygenetic relationships have been identified in intertext: $\mathrm{T}^{3} \leftarrow \mathrm{T}^{1}+$ $\mathrm{T}^{2}$ and $\mathrm{T}^{3} \leftarrow \mathrm{T}^{2} \leftarrow \mathrm{T}^{1}$. In the first case, a fragment of a new text is related to two (and more) unrelated contexts. In the second type, the prototypes used are found within each other, which reconstructs their historicalliterary connection. Intertextuality is closely linked to the hermeneutical principles of the analysis of literary text. Intertextual analysis / interpretation of the text is impossible without a common poetic paradigm and compatible background knowledge of the author and the recipient. That is why the process of reading intertext involves the identification of all the forms of intertextuality presented in the work and the decoding of its subtexts. The interaction is implemented explicitly and implicitly. Explicit interaction initiates the emergence of new implicit meanings. The implicit meaning is hidden, that is, not verbally expressed information. Subtext is a parallel content that is formed directly by implicit meanings. In the narrow sense, the subtext is used in the understanding of the "contextual meaning of the word", and in the broad sense - as "untrue discourse". For our study, the second interpretation is important because it interprets the subtext as a parallel reality, which makes it possible to refer to a literary text and to some extent make up its essence. Analyzing the forms and functions of intertextuality in Eliot's poetry requires a clear classification of the types of text interaction. In this work we will use the following classification:

- its own intertextuality that forms the text-to-text construction;

- paratextuality, or the relation of the text to the title, epigraph, epilogue;

- hypertextuality as ridicule or parody of one text by another;

- architecturalism as a genre connection of texts;

- a poetic paradigm.

According to the source of the borrowing, we will divide the textual links into archetypal and textual ones. 
In the text of art, the phenomenon of intertextuality is actualized with the help of the following texts: attributed quotation, unattributed and unmarked quotation, allusion, reminiscence, mytheme, mythologem, paraphrase, and the introduction of another style. All forms of intertextuality are signs of a particular culture, epoch, or idiocy of any writer (usually a classic), who, in the course of their use, has acquired several occasional subtexts, thereby facilitating the dialogue of texts, writers and cultures.

The "strange word" in the texts of any writer can be classified as precedent and peripheral. The study of precedent writers in the metatext of the writer reflects his cultural-semiotic preferences, and also reproduces the evolution of his work, because at some creative stage these orientations may change. For identifying precedent authors and works in the writer's metatext, we will use the concept of "intertextual framework", which is a kind of matrix of the scale of values of any writer.

\section{SUMMARY}

The article deals with the notion of intertextuality which is canonic for all texts. It overviews intertextuality as the main category of modernist and postmodernist texts. The problem of intertextuality is one of the current research of literary critics, linguists and psycholinguists. Currently, there are a considerable number of interpretations of concepts such as "intertextuality" and "intertext". In the course of my research, preference will be given to the understanding of intertextuality proposed by $\mathrm{R}$. Barthes and refined by Y. Kristeva. At the present stage of its development, fiction delves into self-knowledge and seeks immanent sources and forms of development. It is found that the interaction can be implemented in two manifestations: one-stage and two-stage. The latter is polygenic in nature. The following types of polygenetic relationships have been identified in intertext: $T^{3} \leftarrow T^{1}+T^{2}$ and $T^{3} \leftarrow T^{2} \leftarrow T^{1}$. In the first case, a piece of new text refers to two (or more) unrelated contexts. In the second type, the proto-texts are found within each other, which reconstructs their historical-literary connection. The interaction is implemented explicitly and implicitly. Explicit interaction triggers the emergence of new implicit meanings. The implicit meaning is hidden, that is, not verbally expressed information.

\section{REFERENCES}

1. Dugast J. Themes et motifs dans le roman contemporain. “La Pensee”, 1971. № 158. - P. 82-103. 
2. Арнольд И. В. Читательское восприятие интертекстуальности и герменевтика // Интертекстуальные связи в художественном тексте. - С.-Пб.: Сотворение, 1993. - С. 4-12.

3. Барт Р. Семиотика. Поэтика. - М.: Прогресс, 1994. - 616 с. C. 62 .

4. Бахтін М. Проблема тексту в лінгвістиці, філології та інших гуманітарних науках // Слово. Знак. Дискурс. Антологія світової літературно-критичної думки XX ст. / За ред. Марії Зубрицької. Львів: Літопис, 1996. - С. 321-322.

5. Библер В. С. От наукоучения - к логике культуры: Два философских введения в двадцать первый век. - М.: Политиздат, 1991. 413 с. - С. 286.

6. Володина О. В. Явление интертекстуальности в аспекте типологии // Тр. Междунар. конф. «Взаимодействие литератур в мировом литературном процессе (Проблемы теоретической и исторической поэтики)»: В 2 ч. - Гродно: ГрГУ, 1998. - Ч. 1. - С. 29-38.

7. Гальперин И. Р. Текст как объект лингвистического иследования. - М.: Наука, 1981. - 140 с. - с. 74.

8. Денисова Г. В. В мире интертекста: язык, память, перевод. М.: Азбуковник, 2003. - 297 с.

9. Козлов А. С. Литературоведение Англии и США ХХ века. М.: Московский лицей, 2004. - 256 с. - С. 31.

10. Кристева Ю. Бахтин, слово, диалог и роман // Французская семиотика: от структурализма к постструктурализму / Под. ред. Косикова Г. К. - М.: Прогресс, 2000. - С. 427-457.

11. Кузьмина Н. А. Интертекст и его роль в процесах эволюции поэтического язика. - М.: Едиториал УРСС, 2004. - 272 с. - С. 14.

12. Лексикон загального та порівняльного літературознавства. Чернівці: Золоті литаври, 2001. - 636 с. -612.

13. Літературознавчий сдовник-довідник / Р. Т.Гром'як, Ю. І. Ковалів та ін.- К.: ВЦ «Академія», 1997. - 752 с. - с. - С. 20.

14. Лотман Ю. М. Текст у тексті // Слово. Знак. Дискурс. Антологія світової літературно-критичної думки XX ст. / За ред. Марії Зубрицької. - Львів: Літопис, 1996. - С. 428-442. - С. 436.

15. Машкова Л. А. Алюзия в романе Гофмана «Эликсиры дъявола» // В мире Э. Т. А. Гофмана. - Калининград: Гофман-центр, 1994. - C. 120-131. - С. 25-33.

16. Москвин В. П. Стилистика русского языка. Теоретический курс. - Ростов н/Д.: Феникс, 2006. - 630 с. - С. 202. 
17. Пономаренко I. В. Художня своєрідність поезії Ліни Костенко (інтертекстуальність і феномен Агону): Дис. ... кандидата філол. наук: 10.01.01; - Захищена 18.01.2006; Затв. 13.04.2006. - К., 2005. - 190 с.: іл.-Бібліогр.: с. 173-190. - С. 130.

18. Потебня О. Думка і мова // Антологія світової літературнокритичної думки XX ст. / За редакцією Марії Зубрицької. - Львів: Літопис, 1996. - С. 25-39.

Руднев В. П. Словарь культуры ХХ века: Ключевые понятия и тексты. - М.: АГРАФ, 1999. - 381 с. - С. 256.

19. Селиванова Е. А. Основы лингвистической теории текста и коммуникации. - К.: Издательство украинского фитосоциологического центра, 2002. - 336 с. - С. 221.

20. Слово. Знак. Дискурс. Антологія світової літературнокритичної думки XX ст. / За ред. М. Зубрицької. - Львів: Літопис, 1996. -633 с. - С. 608.

21. Смирнов И. П. Порождение интертекста (элементы интертекстуального анализа с примерами из творчества Б. Пастернака). СПб.: Изд-во С.-Петерб. ун-та, 1995. - 191 с. - С. 205.

22. Тороп П. Х. Проблема интекста // Труды по знаковым системам. Вып. XIV. Текст в тексте. - Тарту: ТГУ, 1981. - С. 33-44. - С. 39.

23. Фатеева Н. А. Контрапункт интертекстуальности, или интертекст в мире текстов. - М.: Агар, 2000. - 280 с.

24. Фоменко И. В. Цитата // Введение в литературоведение: Литературное произведение: основные понятия и термины. - М.: «Высшая школа», 1999. - С. 496-506. - С. 499.

25. Фомичева Ж. Е. Иностилевые скопления как вид интертекстуальности // Интертекстуальные связи в художественном тексте. - С.-Пб.: Сотворение, 1993. - С. 90-92.

26. Элиот Т. С. Традиция и творческая ндивидуальность / Пер. А. Зверева. // Писатели США о литературе. В 2 т. - М.: Прогресс, 1982. - T. 2 - C. 12-19. - C. 56.

\section{Information about the author:} Statkevych L. P., Candidate of Philological Sciences, Associate Professor, Foreign Philology Department, Academic and Scientific Institute of Philology and Journalism

V. I. Vernadsky Taurida National University 33, J. McCain str., Kyiv, 01042, Ukraine 